https://www.amerabra.org; https://fspu.uitm.edu.my/cebs; https://www.emasemasresources.com/ $9^{\text {th }}$ Asian Conference on Environment-Behaviour Studies Perdana Kota Bharu, Kelantan, Malaysia, 28-29 Jul 2021

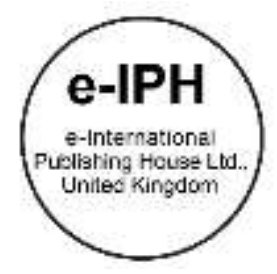

\title{
Procurement of Maintenance Management for Public High Rise Residential Buildings
}

\author{
AbdulLateef Olanrewajuํㅜ, Anis Rosniza Nizam Akbar ${ }^{2}$, Nurul Afiqah Azmi ${ }^{3}$, Tan Rui Hong ${ }^{4}$ \\ 1,4 Universiti Tunku Abdul Rahman, Jalan Universiti, Bandar Barat, 31900, Kampar, Malaysia \\ ${ }^{2}$ Centre of Studies for Quantity Surveyors, Faculty of Architecture, Planning and Surveying, \\ Universiti Teknologi Mara (UiTM), Shah Alam, Malaysia \\ ${ }^{3}$ Centre of Studies for Estate Management, Faculty of Architecture, Planning and Surveying, \\ Universiti Teknologi Mara (UiTM), Shah Alam, Malaysia
}

abdullateef.olanrewaju@gmail.com, anisrosniza@uitm.edu.my,nafiqah@uitm.edu.my, rhtan93@gmail.com

Tel Author1: +6017-603 8175

\begin{abstract}
In response to the Malaysian housing shortage, various interventions have been introduced. However, while the housing gap is widening, problems relating to the performance and condition of the buildings on account of poor maintenance is increasing unabated. This study investigated the selection criteria of maintenance procurement strategies for public high-rise residential buildings through a survey involving eight (8) maintenance managers of PRIMA housings. The five (5) main selection criteria are working relationship intuition and experience, quality level, condition of the existing building, and clarity of scope. The research prompts a need for strategic defect management for public housing.
\end{abstract}

Keywords: PR1MA housing, low-cost housing, AHP, outsourcing

eISSN: 2398-42870 2021. The Authors. Published for AMER ABRA cE-Bs by e-International Publishing House, Ltd., UK. This is an open access article under the CC BYNC-ND license (http://creativecommons.org/licenses/by-nc-nd/4.0/). Peer-review under responsibility of AMER (Association of Malaysian Environment-Behaviour Researchers), ABRA (Association of Behavioural Researchers on Asians/Africans/Arabians) and CE-Bs (Centre for Environment-Behaviour Studies), Faculty of Architecture, Planning \& Surveying, Universiti Teknologi MARA, Malaysia.

DOI: https://doi.org/10.21834/ebpj.v6i17.2882

\subsection{Introduction}

Housing offers individuals and neighbourhoods accommodation, comfort, satisfaction, respect, and vibrant living conditions. The housing performance depends on and is determined by the occupants' wellbeing, education, intellect, and behaviour. Housing is now connected to health issues (WHO, 2018). Housing has been identified as a national agenda in most countries regardless of whether the country is underdeveloped, developing, and developed through the formulations and implementations of policies. However, the housing shortage is a global problem (Urban Reform Institute, 2021). In response to the housing shortage in Malaysia, the Government has introduced various housing programs and schemes for low- and middle-income households to increase homeownership. However, while the housing gap is widening, problems relating to performance and condition on account of defects in the affordable housing stock is increasing unabated (Olanrewaju and Woon, 2017). Extant literature revealed that the extent of defects in affordable in Malaysia is vast, increasing and has been a significant source of dissatisfactions among buyers and leading to disputes and litigations leading to affordable defects are ramparts in affordable housing (Suffian, 2013, Che-Ghani, et al., 2016, Abdul-Rahman, et al., 2014 and Olanrewaju, et al., 2021). The high operation and maintenance costs of affordable are making affordable housing unaffordable.

eISSN: 2398-4287C 2021. The Authors. Published for AMER ABRA cE-Bs by e-International Publishing House, Ltd., UK. This is an open access article under the CC BYNC-ND license (http://creativecommons.org/licenses/by-nc-nd/4.0/). Peer-review under responsibility of AMER (Association of Malaysian Environment-Behaviour Researchers), ABRA (Association of Behavioural Researchers on Asians/Africans/Arabians) and cE-Bs (Centre for Environment-Behaviour Studies), Faculty of Architecture, Planning \& Surveying, Universiti Teknologi MARA, Malaysia.

DOI: https://doi.org/10.21834/ebpj.v6i17.2882 
As Olanrewaju et al. (2017) explained, housing is not affordable, to the extent that the homebuyers will pay more for transportation, feeding, and health, on account of their house price. Poor maintenance of the affordable has been a significant source of discontent among the homebuyers and property developers. However, a significant reason for poor maintenance is the procurement strategy for the maintenance service, mainly dependent on the selection criteria. Inadequate selection criteria will lead to selecting the wrong strategy, leading to poor performance of the maintenance organizations. Therefore, this study investigated the selection criteria for the procurement of maintenance services by the public housing developers to explain the possible reasons for the poor maintenance of high-rise residential buildings in Malaysia.

\subsection{Background and conceptual justification}

Housing is a contributing factor to national economic growth and development because national wellbeing and productivity are related to the sufficiency and quality of the housing. The housing performance correlated to occupants' health, satisfaction, education, intelligence, and behaviour. To accelerate the housing supply, the Government directly provides housing and alliances with private sectors in most countries. While the term "affordable housing" has multiple meanings, it is used here to refer to housing for people in the middle-income group. While affordable housing shortage is a global problem (Urban Reform Institute, 2021), defects or snagging are common in most affordable housing globally (Forcada et al., 2014; Sommerville and McCosh, 2006; Pan and Thomas, 2014; Craig et al., 2010 and Olanrewaju, et al., 2021). Similarly, Olanrewaju and Woon (2017) surmised that many affordable housings in Malaysia face pre-occupancy obsolesces. By this, they mean that even before occupants move into their new homes, they have numerous defects. This issue is a global problem; in fact, research on defects in the residential building has been conducted in many countries (Shirkavand et al., 2016; Hopkin et al., 2016; Chong and Low, 2005; Christudason, 2007; Abdul-Rahman et al., 2014 and Rotimi, et al., 2015). The inadequacies of affordable housing supply are known to the Malaysian Government, and to curtail the housing shortage, many schemes, incentives, programs, and interventions have been introduced. Some of the latest measures include; The Perumahan Rakyat 1Malaysia (PR1MA), 1Malaysia Civil Servants Housing (PPA1M), Rumah Wilayah Persekutuan (RUMAWIP), Skim Perumahan Mampu Milik Swasta (MyHome), The Program Perumahan Rakyat (PPR), Program Rumah Mampu Milik (RMM)) Federal Land Development Authority (FELDA), Skim Perumahan Mampu Milik Swasta (MyHome), Rumah Mesra Rakyat 1Malaysia (RMR1M), Rumah Mampu Milik Wilayah Persekutuan (RUMAWIP), Rumah Selangorku, Umah Idaman Rakyat (RIR).

\subsection{The Perumahan Rakyat 1Malaysia (PR1MA)}

PR1MA project is established in January 2013 to plan, develop, construct, maintain, and operate comprehensive and comfortable residential communities in Malaysia's urban and suburban areas (Perbadanan PR1MA Malaysia, 2017). The program aims to build 500,000 housing units. The price per unit ranges from RM 100,000 to RM 400,000. The buyers must be Malaysian, at least 21-year-old, with an individual or combined household income between RM 2,500 to RM 15,000, and own no more than one property. Until 31 March 2017, a total of 136,609 units of PR1MA homes are in various stages of construction (PR1MA Annual Report 2016). While there are no specific data on defects in the housing, there are increasing criticisms and complaints from the homebuyers and users on poor performance. The size, complexity, and nature of the defects in affordable housing have led the Government to introduce various schemes and programs to increase the performance and condition of the housing. For instance, Program Penyenggaraan Perumahan (PPP) was introduced in 2011. RM500 million was allocated for the maintenance of low-cost public housing. The PPP involves major repairs and maintenance works, including repainting, repair /replacement of lifts, water tanks, and sanitary system of the affordable housing. Tabung Perumahan 1Malaysia (TP1M) was introduced with an initial fund of RM180 million to maintain affordable housing in 2012. In 2015, the Government allocated RM105 million for the maintenance of Government quarters. Furthermore, the Strata Management Act, 2013 (Act 757) was enacted in 2013 to replace Building and Common Property (Maintenance and Management). However, despite the various interventions on the maintenance of affordable housing, the housing condition and performance are subject to continued criticism, especially in the media. However, the major problems are attributed to the contractual and administrative matters between the clients (PR1MA) and the maintenance contractors. Furthermore, poor planning of the maintenance management for the public building has been identified as the main problem (Lim et al., 2015 and Hauashdh et al., 2020).

\subsection{Procurement of building maintenance services}

The various types of procurement strategies reflect the extent to which the client is willing and able to bear a certain level of risks measure in terms of cost, quality and time, and other criteria within the client value system (Olanrewaju and Abdul-Aziz, 2015). Different procurement maintenance strategies are available to meet different needs and conditions. The building maintenance function is management decisions (Faremi et al., 2017). While some organizations insource the maintenance service delivery, some outsource all the work, but many organizations combine both methods based on the project requirement. Outsourcing is rampant because most housing organizations lack competent maintenance organizations and prefer to outsource their non-core activities. While strategies like cost-plus or cost reimbursement may be appropriate for some projects, day work or lump sum may be the most suitable for some clients. The lack of specificity for the procurement strategies for maintenance services makes the procurement of maintenance works more complicated and tedious than newly built ones (Fouladgar et al., 2012). Accurate information on the quantities and quality of the works for maintenance are seldom available before a contract is signed. The bill of dilapidation, if available, is usually inaccurate and is, in fact, misleading. In capital procurement, the contract covers legal matters in case of disputes among parties, but in the case of a maintenance contract, the maintenance contract is more of instruction. As Olanrewaju et al. (2018) explained, the decision of procurement strategies is the most critical element in a decision on maintenance services. 


\subsection{Outline of research design}

This study consists of a literature review and a survey. The primary data collected were based on convenience sampling. Convenience sampling is inductive. Convenience sampling is a data collection method where the survey is administered to available, accessible, and willing respondents (Olanrewaju et al., 2021). The method is appropriate where sufficient information on population size and sample frame is not available. However, although their results may not be generalizable, they may represent when large sample size is used (Sekaran and Bougie, 2016). The questionnaires were distributed to respondents through online surveys over two weeks (i.e., 3/17/2021 through 3/27/2021). The selection criteria for the maintenance services were measured using the pair-wise comparison method. The procedure entails breaking down criteria into pair-wise comparisons and then synthesizing the findings into degrees of priority. In other words, each of the criteria is pair-wise against one another to obtain their individual weight. The pair-wise comparison judgments were made concerning the attributes of one level of hierarchy given the attribute of the next higher level of hierarchy (from the main criteria to the sub-criteria).

However, the sub-criteria were not involved in this research. The pair-wise technique is similar to comparisons performed in Analytical Hierarchy Process (AHP). This method is adopted because the sample size (only housing completed more than one (1) years is included for a practical reason) is small. Hence the results of the Likert scale may not be appropriate.

(1)due to the COVID-19 pandemic, it becomes tough to conduct interviews with the maintenance organizations (2); the pair-wise is suitable because many of the selection criteria are subjective (3); the maintenance managers were asked based on evidence on the procurement or contract of the maintenance services, to prioritize the criteria that they considered to make a decision on the procurement of the maintenance services against the other criteria on a scale of; $1=$ Less Importance, $2=$ Weak importance, $3=$ Moderate importance, 4= Moderate Plus, 5= Strong importance, 6= Strong plus, 7= Very strong or demonstrate the importance, 8= Very, Very strong and 9= Extreme Importance. The selection criteria were collected from Olanrewaju and Abdul-Aziz, (2015), Chua et al. (2014), and the authors' experience. The priority level of criteria is determined by the average importance index (i.e., Mean score) for straightforward interpretation as the number of criteria is many. Since the criteria are many, there is the likelihood of inconsistency to increase due to overlapping.

\subsection{Findings}

Four (4) of the respondents were Maintenance Executive, two (2) were Facility Manager, whereby one each is Maintenance Manager and Facilities Management Executive. Six (6) of the respondents have between two (2) and four (4) years of work experience. While one (1) has less than a year of work experience, one (1) has more than five (5) years of work experience. All respondents got bachelor's degrees. Five (5) of them are facility managers, while the remaining three (3) are quantity surveyors, real estate managers, and engineers, respectively. The average size of the building is 7.5 acres (ranges from less than 5 acres to between 10 and 15 acres). The buildings are relatively new at an average of 3 years old. The annual maintenance budget for each of the buildings exceeds RM400,000:00. Estimating maintenance work is mainly based on the previous year's expenditures, considering the building's condition. However, in one of the housings, building condition is considered in estimating the maintenance budget. Table 1 contains the descriptive results of evaluating criteria used in selecting procurement for the PR1MA housing. The overall index is 5.088, and the average standard deviation is 1.015. Thirteen (13) of the criteria scored more than the average score. Explanations were provided for only the 13 criteria due to space constraints.

Table 1. Results of selection criteria for the procurement of maintenance services

\begin{tabular}{|c|c|c|c|}
\hline Criteria & Std. Deviation & Index & Priority \\
\hline The working relationship between the client and the maintenance contractor & 0.518 & 8.63 & 1 \\
\hline Intuition and past experience of the decision-maker to select procurement method for maintenance services & 0.886 & 8.25 & 2 \\
\hline The quality level of Maintenance services & 0.641 & 8.13 & 3 \\
\hline Condition of existing building when selecting procurement method & 1.126 & 7.88 & 4 \\
\hline Clarity of scope with well-defined for the maintenance contractor in a project & 1.246 & 7.13 & 5 \\
\hline Availability of experienced contractor with the client prefer procurement method & 1.309 & 7.00 & 6 \\
\hline Government policy for high rise building maintenance services & 0.916 & 6.63 & 7 \\
\hline Price competition among tenders & 0.886 & 6.25 & 8 \\
\hline Time certainty & 1.246 & 6.13 & 9 \\
\hline Client's financial capability for maintenance services & 0.991 & 5.88 & 10 \\
\hline Risk allocation/avoidance & 0.926 & 5.50 & 11 \\
\hline Age of the building during tendering & 1.397 & 5.43 & 12 \\
\hline Degree of adaptability of maintenance contractor to the procurement method & 0.991 & 5.13 & 13 \\
\hline Public accountability for environmental friendliness and cost reduction & 1.302 & 4.38 & 14 \\
\hline Price/Cost certainty & 1.165 & 4.25 & 15 \\
\hline Capability in house technical to perform some maintenance work & 1.126 & 4.13 & 16 \\
\hline Methods of disputes resolutions & 0.535 & 3.50 & 17 \\
\hline Experience with the previous procurement method if any & 0.926 & 3.50 & 18 \\
\hline Objective or maintenance policy of PR1MA organization & 1.356 & 2.88 & 19 \\
\hline Size of maintenance work & 0.518 & 2.62 & 20 \\
\hline Involvement of owner/ client in-house organization in the maintenance project & 1.685 & 2.38 & 21 \\
\hline Degree of flexibility for the variation in the maintenance work & 0.707 & 2.25 & 22 \\
\hline Degree of complexity within the maintenance project & 1.035 & 2.25 & 23 \\
\hline Location of the buildings & 0.926 & 2.00 & 24 \\
\hline
\end{tabular}




\subsection{Discussion}

Due to space constraints, only the first 13 selection criteria with individual index scores more than the average index (i.e. 5.088.) are discussed. It is not unexpected to find that the most important criterion for selecting a maintenance service procurement is the working relationship between the client and the maintenance contractor. A salient point here is that the maintenance services are always outsourced because maintenance is a necessary evil (i.e., waste) that will cost what it will cost whatever the maintenance organizations do (Olanrewaju et al., 2018). It will also mean that maintenance is still considered a purely technical function. Maintenance work cannot be predicted accurately (Olanrewaju and Abdul Rashid, 2015). Bills of dilapidations are often unreliable, and the defect is cancerous. It would spread to every part of the building very fast without maintenance. Many of the defects may not be visible to client organizations (i.e., PR1MA). Therefore, since the extent and nature of work involved are unknown, it is not surprising that the working relationship between the maintenance organizations and clients will be a paramount condition, and by extension, the question of trust management is strategic. Hence, it is anticipated that clients will select a suitable method based on their awareness and experience on the procurement method taken into account the available information on the nature and extent of defects in the buildings. The quality level of maintenance services is also related to the past working relationship between the client organization and the maintenance contractors.

While the clients may require the maintenance contractors to submit the list of their previously completed projects as part of the tender documents for prequalification purposes, such information is not often substantiated. Hence, the clients would most often depend on the past working experience with the contractors to evaluate the quality of the services the maintenance contractors can offer. However, if there is no information on the past relationship between the parties, a recommendation from the maintenance contractor's previous clients may be required. Maintenance is needed when the satisfaction of homebuyers or home-users is affected by the building's condition or performance. While some procurement strategies are suitable for corrective maintenance, others may not (Kirkham, 2007). Our data also revealed that the condition of the building is a decisive selection criterion. This is anticipated. In other words, the corrective maintenance strategy is dominant for affordable housing. Corrective maintenance is often required when time is of the essence, in which the maintenance contractors are required to start repair immediately. However, corrective maintenance is also initiated due to a lack of funds or poor maintenance management practice. To base maintenance decisions on the building condition is reactive and cost-driven (Wong et al., 2021) and does not add value to the clients and users.

Maintenance clients would also account for the information on the scope of maintenance in selecting maintenance contractors. This is instructive because the scope of maintenance is often unclear during the tendering process. Hence, the traditional procurement strategies may be counter-productive. This may call for approaches like cost reimbursement and construction management). Hence, it does not come as a surprise that the availability of experience of the maintenance contractors with each procurement strategy is significant. The procurement process and requirements for a new building are different for maintenance, refurbishment, extension, and rehabilitation. Each of the different housing schemes is guided by government policy. For the PR1MA housing, maintenance services are provided by the PR1MA organization directly or indirectly. The PR1MA engages the maintenance contractors to provide all the maintenance services by having a maintenance office in each housing scheme. However, it is not all the maintenance services are covered by the maintenance contractors. Some of the maintenance that may arise may be beyond the works as defined in the contract document. In each case, the client may negotiate the work if the contractors can execute the work. However, if the contractors cannot cover the new work or the scope is beyond the contractor's capability, the clients would invite tenders from other maintenance contractors. This is related to the eighth selection criterion of pricing competition among the tenderers. Tender price and the completion schedule were significant criteria in deciding on a suitable maintenance strategy. If maintenance is completed as scheduled, on the one hand, the price of the maintenance works may increase on absolute terms, and on the other hand, the decayed portions would worsen and even spread of the other parts that were not initiated damaged. Every housing scheme is budget-constrained, and most of the maintenance depends on the Government revenue since PR1MA is considered an affordable housing scheme; therefore, the Government aims to lessen the burden of homebuyers.

Each procurement strategy indicates the level of risk that either the clients or the maintenance organization are willing and able to averse or absorb risk (Olanrewaju and Abdul Rashid, 2015). Maintenance organizations that adopt a value-based approach will have a good maintenance culture and should be risk-takers by nature. However, most maintenance clients are risk-averse. By implication, maintenance clients may not prefer cost reimbursement, cost-plus, construction management would prefer strategies like the lump sum contract, based on bills of firm quantities for their maintenance works. The age of a building has been one of the major criteria for maintenance demand in buildings. In general, as building aged, more maintenance is required as the maintenance materials and component has a finite lifespan that depends on age. In fact, preventive and condition-based maintenance is based on the age of the buildings and their components. Because of this, it is not surprising that the age of the building is a major selection criterion. The thirteenth criterion is adaptability or familiarity of the contractor with the client's preferred procurement strategy. Due to lack of experience and risk culture, some maintenance contractors may not be able to adapt to client procurement strategy, and those that are able to adopt may have an upper chance to win a contractor. Each of the maintenance contractors is good at a specific maintenance trade. For instance, some specialized in the foundation, some specialized in roofing repair, and some specialized in the building engineering service (mechanical and electrical services). The speciality of the maintenance contractors is related to the procurement method.

\subsection{Conclusion \& Recommendations}

The is research has investigated the selecting criteria for procurement strategy for high-rise residential buildings in Malaysia. However, from an ontological point of view, the main findings of this research are on the procurement of high residential buildings that are generalizable to other types of affordable housing schemes in and outside of Malaysia. It is obvious from the findings that the cost of 
maintenance is not the major criterion. The longer relationship between the housing providers/clients with the maintenance contractors is very significant. They also indicate that maintenance planning requires critical analysis of building conditions, and the scope of the repair occupied considerable positions. Although homeowner's satisfaction was mistakenly omitted from the list of the selection criteria, the quality of maintenance time completion of the maintenance and the condition of the building could be a pointer that the experiences of homebuyers/users are considered. In order to maximize the maintenance budget, a procurement strategy that emphasizes building performance and users' satisfaction should highly be considered. The procurement strategy and extension maintenance service delivery are part of the building maintenance management process. The study is estimated to increase buildings, defect management, homebuyers' satisfaction, and justification for the maintenance budget and expenditure. It will increase public transparency and accountability of government expenditure. Before inviting maintenance contractors, the in-house maintenance organization should conduct a condition and performance audit of the buildings. It should be supported with document analysis and interview with the stakeholders (users) to reduce claims and disputes and where such information is available. The maintenance should be aware of this to know the level of risk they are exposed to if selected for the maintenance. Although this has provided insight into the selection of maintenance procurement strategies, the results may not be generalized because of the sampling method. Future research may increase the sample size and revise the criteria.

\section{Acknowledgements}

The authors would like to extend the utmost appreciation to Universiti Tunku Abdul Rahman, Kampar and Universiti Teknologi MARA Shah Alam for the success of this research.

\section{Paper Contribution to Related Field of Study}

The findings of this research hold critical theoretical and practical implications for future research of procurement the housing maintenance service. Ontologically, the main findings are generalizable to the maintenance management services of other types of buildings in and outside of Malaysia.

\section{References}

Abdul-Rahman, H., Wang, C., Wood, L. C., \& Khoo, Y. M. (2014). Defects in affordable housing projects in Klang Valley, Malaysia. Journal of Performance of Constructed Facilities, 28(2), 272-285

Che-Ghani, N. Z., Myeda, N. E., \& Ali, A. S. (2016). Operations and maintenance cost for stratified buildings: a critical review. In MATEC Web of Conferences (Vol. 66, p. 00041). EDP Sciences.

Chong, W. K., \& Low, S. P. (2005). Assessment of defects at construction and occupancy stages. Journal of Performance of Constructed facilities, $19(4), 283-289$.

Christudason, A. (2007). Defects in common property of strata developments in Singapore: representative actions against developers. Structural Survey, 25(3/4), 306318.

Chua, S. J. L., Ali, A. S., \& Alias, A. (2014). Procurement method selection for building maintenance projects: the case of Malaysian public universities. World Journal of Engineering and Technology, 2(3), 7-13.

Craig, N., Sommerville, J., \& Auchterlounie, T. (2010, September). Customer satisfaction and snagging in the UK private house building sector. In Proc., 26th Annual ARCOM Conf (pp. 1199-1208). Association of Researchers in Construction Management, Leeds, UK.

Faremi, O., Adenuga, O., \& Ameh, J. (2017). Maintenance management sourcing strategies and the condition of tertiary institution buildings in Lagos and Ogun States, Nigeria. Ethiopian Journal of Environmental Studies and Management, 10(1), 64-74.

Forcada, N., Macarulla, M., Gangolells, M., \& Casals, M. (2014). Assessment of construction defects in residential buildings in Spain. Building Research \& Information $42(5), 629-640$.

Fouladgar, M. M., Yazdani-Chamzini, A., Lashgari, A., Zavadskas, E. K., \& Turskis, Z. (2012). Maintenance strategy selection using AHP and COPRAS under fuzzy environment. International journal of strategic property management, 16(1), 85-104.

Hauashdh, A., Jailani, J., \& Rahman, I. A. (2020). Building maintenance practices in Malaysia: a systematic review of issues, effects and the way forward. International Journal of Building Pathology and Adaptation. Vol. 38 No. 5, 2020 pp. pp653-672

Hopkin, T., Lu, S. L., Rogers, P., \& Sexton, M. (2016). Detecting defects in the UK new-build housing sector: a learning perspective. Construction Management and Economics, 34(1), 35-45.

Kirkham, R. (2007), Ferry and Brandon's cost planning of buildings. 8th Edition. UK: Blackwell Publishing Limited

Lim, X.Y., Olanrewaju, A.L., and Tan S.Y., (2015). "Strategies for Affordable Housing Delivery.” Australian Journal of Basic and Applied Sciences. 9 (25), 118-124.

Olanrewaju A.L and Abdul-Aziz A. R. (2015). Building maintenance processes and practices: The case of a fast-developing country. Springer; 
Olanrewaju, A., Fang, W. W., \& Tan, Y. S. (2018). Hospital building maintenance management model. International Journal of Engineering and Technology, 7(2), 747753

Olanrewaju, A., Tan, Y. Y., \& Soh, S. N. (2021). Defect characterisations in the Malaysian affordable housing. International Journal of Building Pathology and Adaptation.

Olanrewaju, A. and Woon, T.C. (2017). An exploration of determinants of affordable housing choice, International Journal of Housing Markets and Analysis, Vol. 10 No. 5, pp. 703-723.

Pan, W., \& Thomas, R. (2014). Defects and Their Influencing Factors of Posthandover New-Build Homes. Journal of Performance of Constructed Facilities, 29(4), 04014119 .

PR1MA Annual Report (2016). Creating Values: Realising Dreams. Perbadanan PR1MA Malaysia.www.pr1ma.my

Rotimi, F. E., Tookey, J., \& Rotimi, J. O. (2015). Evaluating defect reporting in new residential buildings in New Zealand. Buildings, 5(1), 39-55.

Schultz, C. S., Jørgensen, K., Bonke, S., \& Rasmussen, G. M. G. (2015). Building defects in Danish construction: project characteristics influencing the occurrence of defects at handover. Architectural Engineering and Design Management, 11(6), 423-439.

Sekaran, U., \& Bougie, R. (2016). Research methods for business: A skill building approach. John Wiley \& Sons.

Shirkavand, I., Lohne, J., \& Lædre, O. (2016). Defects at handover in Norwegian construction projects. Procedia-Social and Behavioral Sciences, 226, 3-11.

Sommerville, J. and MoCosh, J. (2006), "Defects in homes: an analysis of data on 1,696 new UK houses" Journal of Structural Survey, Vol. 24 No. 1 pp.6-21.

Suffian, A. (2013). Some common maintenance problems and building defects: Our experiences. Procedia Engineering, 54, 101-108.

Urban Reform Institute (2021) Demographia International Housing Affordability 2021 Edition. tourbanreforminstitute.org.

World Health Organization. (2018). WHO housing and health guidelines.http://www/who.int.phe

Wong, W. F., Olanrewaju, A., \& Lim, P. I. (2021). Value-Based Building Maintenance Practices for Public Hospitals in Malaysia. Sustainability, 13(11), 6200. 